e-ISSN: 2622-3597. Available online at https://jurnal.umj.ac.id/index.php/ELIF

Peer-review under responsibility of Muhammadiyah University of Jakarta, Indonesia

\title{
Multiple Intelligences (MI) on Developing Speaking Skills
}

\author{
Shelawati Rizqiningsih 1), Muhamad Sofian Hadi') \\ 1) MTs Al Ihsan, Palmerah, Jakarta Indonesia \\ 2) Universitas Muhammadiyah Jakarta, South Tangerang, Banten, Indonesia \\ 1)Shelawati84@gmail.com, 2) M_Sofianhadi@yahoo.com
}

\begin{abstract}
The current study investigates the impact of multiple intelligences-based Instructions on developing speaking skills of the students of English. Therefore, the problem of the current study can be stated in the lack of speaking skills of the students of English school in Junior High School, MTs Al-Ihsan Jakarta Barat. To confront this problem, the researcher developed a multiple intelligences-based program to enhance the speaking skills paying due attention to the individual differences among students. The sample of the study consisted of sixty fourth-year perspective students of English. The Quasiexperimental research design was used in the study as the researcher used the one group post-test to assess the usefulness of using this approach. Results of the study proved the effectiveness of Multiple Intelligences-(MI) On Developing Speaking Skills of the $9^{\text {th }}$ Grade Students' of MTs Al-Ihsan Jakarta Barat.
\end{abstract}

Keywords: multiple intelligences, speaking skills, the $9^{\text {th }}$ Grade students of English Citation APA Style: Rizqiningsih, S., \& Hadi, M. S. (2019). Multiple Intelligences (MI) on Developing Speaking Skills. English Language in Focus (ELIF), 1(2), 127136.

\section{INTRODUCTION}

$\mathrm{N}$ owadays, English is one of the foreign languages that is more popular than any other languages in the world. Every day, millions of people use English in the workplace and in social life. English is the language most often used language to communicate with other people. In Indonesia, English is taught as foreign language from primary until university level and as one of compulsory subjects. In the context of teaching English, there are four language skills that the students should master: listening, speaking, reading and writing.
Based on Competence Based Curriculum, speaking is one of the four basic competences that the students should

The learning of speaking cannot be separated from language so that speaking should make the students master this aspect. Speaking is a productive skill of language learning. It involves communicative performance, and other important elements, such as pronunciation, intonation, grammar, vocabulary, etc. They should be taught in any language learning to make the learners able to use the target language to communicate. Speaking is the skill that 
the learners will be judged upon most in real-life situation. It is an important part of everyday interaction and most often the first impression of a person is based on his/her ability to speak fluently and comprehensible. Thus, the teachers have a responsibility to prepare the learners as much as possible to be able to speak English in the real-life situation.

Teachers in teaching English, mostly use traditional method (Kramsch, 1993), like explaining the material. It makes students bored. On the other hand, the teachers do not use media and they never change the method. Teachers just give the students test. However, there are many problems faced by the students in learning this language. The students said that English is so difficult to understand, difficult to read because of different writing, spelling, and pronunciation. Besides, they are afraid to speak English because they are not confident to do it, and then they think English is a boring lesson and less interactive. This can be seen in the speaking activities, which consist of drilling materials in the textbook, practicing the material, and finally producing the task based on the text in the worksheet. There are no variations of learning English speaking which could engage students to be more involved in the activities. In the classroom, the process of teaching and learning tends to be monotonous. This makes the process of learning speaking tend to be passive and uninteresting. It affects the students' motivation in learning English. Besides, the activities implemented by the teacher are sometimes not interactive. It makes the students become low in speaking skill, and are not creative in speaking.
English teachers should be creative in teaching English and should upgrade the method Thus, teaching method is the important thing that the teachers use in teaching. The teachers should create good atmosphere, improve students' speaking skill, use the method with the media to make the students interest and active in the class in learning speaking skills. There are many methods in teaching speaking and one of them is news anchor by audio-lingual method. This is an effective method to make the students more interested in learning speaking because they can enrich their vocabulary, improve their pronunciation, and can be active in speaking. They repeat the news anchor, although at first they did not understand the meaning by repeatedly responding to the stimulus provided by the teacher, they would gradually understand the habituation. In news anchor, by audio-lingual the teacher plays a role to keep students' attention with repetitions.

Based on the background above, the writer is interested in taking up the tittle of her study on "Multiple Intelligences (MI) on Developing Speaking Skill of The $9^{\text {th }}$ Grade Students of MTs Al-Ihsan Jakarta Barat".

\section{Speaking}

Every people has to speak when they want to communicate with others people. As stated by Channey in Jondeya (2011, p. 14), in speaking, people will share meaning by producing and receiving information through verbal and non-verbal symbols in a variety of context. In speaking, people express their thoughts through words and talk about perception, feeling, and intentions they 
want other people to grasp and understand.

There are some definitions of speaking. To start with, Nunan (2002) defined that speaking is the productive oral skill and it consists of producing systematic verbal utterance to convey meaning. It is the process of sharing knowledge, emotions, needs, opinion or ideas that take place between the speaker and the listener. So, English teachers should activate students' speaking ability by providing communicative language activities in classroom and then give them opportunities to practice their speaking skill as much as possible.

According to Kathleen (2005), speaking is a process of interaction where speakers intend to build meaning through producing, receiving and processing information. From those theories, the researcher concludes that speaking is important in communicating with other people and it is used as $\mathrm{V}$ media to show ideas, opinions, thoughts and feeling to other. Based on some opinion given above, the writer infers that speaking is an ability to produce some sound articulation used to deliver information, expression, ideas, thought, and feeling. Speaking includes social interaction with other people so that people must know the components of speaking.

\section{Function of Speaking}

There are many functions of speaking proposed by many practitioners. According to Brown and Yule as cited in Richards (2008), there are three functions of speaking; speaking as interaction, speaking as performance, and speaking as transaction. Speaking as interaction refers to the interaction which serves a primarily social function. When people meet, they exchange greetings, engage in small speaking and chit chat, recount recent experiences because they wish to be friendly and to establish a comfortable zone of interaction with others. The focus is more on the speaker and how they wish to present themselves to each other.

Speaking as performance refers to public speaking; it is talk which transmits information before an audience such as public announcements and speeches. Speaking as performance tends to be in form of monolog rather than dialogue, often follow a rezcognizable format and it is closer to written language than conversational language.

Speaking as transaction refers to situation where the focus is on the message about what is said or achieved in order to make people understood clearly and accurately.

\section{The Components of Speaking}

Students must practice to speak English as often as possible so that they will be able to speak English fluently and accurately. Thus, they have to know some important components. The components of speaking are what aspect influencing how well people speak English. Here are the components of speaking skills:

Grammar is needed for the students to arrange correct sentences in conversation both in written and oral forms. Grammar is defined as a systematic way of accounting for and predicting an ideal speaker's or hearer's knowledge of the language. This is done by a set of rules or principles that can be 
used to generate all well-formed or grammatical utterances in the language (Purpura, 2013). Moreover, the other definition of grammar stated by Greenbaum \& Nelson (1996) who argued that Grammar refers to the set of rules that allow people to combine words in their language into larger units.

The grammar of a language is the description of the ways in which words can change their forms and can be combined into sentences in that language (Harmer, 2001, p. 12). Thus, from the statements above it can be concluded that the function of grammar is to arrange the correct meaning of sentences based on the context; in addition, it is used to avoid misunderstanding in each communicator.

Vocabulary means the appropriate diction or the most important thing in a language especially in speaking; furthermore, knowing many vocabularies will make people easier to express their ideas, feeling and thoughts both in oral or written form. According to Turk (2003), In spoken language, the vocabulary tends to be familiar and every day. It means that in spoken language or speaking, the vocabulary used must be very familiar and it is used in everyday conversation in order to understand the spoken discourse. Vocabulary is a basic building block of language learning. Students need to know words, their meanings, how they are spelled and how they are pronounced.

Pronunciation is the way for students to produce clearer language when they speak. It deals with the phonological process that refers to the components of grammar made up of the elements and principles that determine how sounds vary and pattern in a language. The students can communicate effectively when they have good pronunciation and intonation even though they have limited vocabulary and grammar. Pronunciation refers to the traditional or customary utterance of words. From that statement can be concluded that pronunciation is the way for students to produce the utterance words clearly when they are speaking (Kline, 2001, p. 69).

Fluency can be defined as the ability to speak fluently and accurately. Fluency in speaking is the aim of many language learners. Signs of fluency include a reasonably fast speed of speaking and only a small number of pauses and "ums" or "ers". These signs indicate that the speaker does not have to spend a lot of time searching for the language items needed to express the message (Brown. 1997, p. 4). Fluency is defined as the ability to speak communicatively, fluently and accurately.

Comprehension refers to the fact that participants fully understand the nature of the research project, even when procedures are complicated and entail risks (Cohen et al., 2005, p. 51). Comprehension is ability to understand. When people want to talk about a topic (anything topic), they should know and understand all of thing about the topic.

\section{Multiple Intelligences}

One of the most remarkable features of the theory of multiple intelligences is how it provides eight different potential pathways to learning. According Campbell (2015, p. 2-3), theory of multiple intelligences suggests several other ways in which the material 
might be presented to facilitate effective learning. Whether you are a kindergarten teacher, a graduate school instructor, or an adult learner seeking better ways of pursuing self-study on any subject of interest, the same basic guidelines apply.

Whatever researchers are teaching or learning, see how you might connect it with words (linguistic intelligence), numbers or logic (logicalmathematical intelligence), pictures (spatial intelligence), music (musical intelligence), self-reflection (intrapersonal intelligence), a physical experience (bodily-kinesthetic intelligence), a social experience (interpersonal intelligence).

experience in the natural world. Jasmine (2015, p. 11-12) (Naturalist intelligence)For example, if you're teaching or learning about the law of supply and demand in economics, you might read about it (linguistic), study mathematical formulas that express it (logical-mathematical), examine a graphic chart that illustrates the principle (spatial), observe the law in the natural world (naturalist).

In the human world of commerce (interpersonal). examine the law in terms of your own body. Example when you supply your body with lots of food, the hunger demand goes down; when there's very little supply, your stomach's demand for food goes way up and you get hungry (bodily-kinesthetic and intrapersonal); and/or write a song (or find an existing song) that demonstrates the law (perhaps Dylan's “Too Much of Nothing?"). Researcher don't have to teach or learn something in all eight ways, just see what the possibilities are, and then decide which particular pathways interest you the most, or seem to be the most effective teaching or learning tools. The theory of multiple intelligences is so intriguing because it expands our horizon of available teaching/learning tools beyond the conventional linguistic and logical methods used in most schools. (Nunan, 2002)Example. Lecture, textbooks, writing assignments, formulas, etc. To get started, put the topic of whatever you're interested in teaching or learning about in the center of a blank sheet of paper, and draw eight straight lines or "spokes" radiating out from this topic. Label each line with a different intelligence. Then start brainstorming ideas for teaching or learning that topic and write down ideas next to each intelligence Hoerr (2016, p. 14-16)

This is a spatial-linguistic approach of brainstorming; you might want to do this in other ways as well, using a tape-recorder, having a group brainstorming session, etc. The current study is of special significance for the prospective students, the study adopts a new theory (MI Theory) in the field of English Language Teaching, which may result in many useful implications for students, teachers, and researchers.

MI Theory calls for multi-modal teaching strategies in which students are given more chances or options while they are learning and speaking. Multiple intelligences theory based instruction helps in involving and reaching more and more students in the learning process because it addresses various types of intelligences whether these intelligences are scholastic (verbal/linguistic intelligences and the logical/mathematical intelligences) or 
non-scholastic intelligences (interpersonal, intrapersonal, and bodilykinesthetic intelligences, etc.) (Crow, 2011, p. 228).

It also calls for giving due care for the speaking skills because of the ultimate importance of these skills in the School or as a necessity for applying for certain jobs. Furthermore, Prospective students should develop their speaking skills to be able to develop these skills once they become students of English at schools. Mastering speaking skills are very important for those prospective students because they will be involved in situations that require them to be welltrained in such important skills.

In addition, according to Penrose and Lave (2012, p. 27) the study is also hoped that this study will help them develop teaching method knowledge to meet the needs of the school future based on the learner-centered approach. The ultimate goal of language use is to achieve communicative purposes. Language learners use language functionally in their daily life to different extents.

\section{RESEARCH METHODOLOGY}

$\mathrm{T}$ this research, the writer used quantitative method with Quasi experimental design to complete this research. According to Arnold (2013, p. 11), quantitative method is an inductive, objective and scientific method in which data are summed up by numbers (scores, values), and analyzed by statistical analysis. In this research, the students in experimental class were though by using Multiple Intelligences (MI) on Developing Speaking Skill of the

\author{
$9^{\text {th }}$ Grade Students of MTs Al-Ihsan \\ Jakarta Barat.
}

The instrument of this research was post-test. The writer used oral test to collect the data. The writer asked the students to make a dialog conversation with friend about Television Host. They were given 3 minutes to speak and asked to use good English covering vocabulary, grammar, pronunciation, fluency and comprehension with good self-confident in front of the class. The post test was given after the treatment to both experimental and control classes. The population of this research was all $9^{\text {th }}$ grade students of MTs Al-Ihsan. The sample in this research is the writer chooses two classes were selected. As an experimental class, which consisted of 36 students as a control class, which consisted of 36 students.

In collecting the data, the writer only used post-test to see whether Multiple Intelligences (MI) on Developing Speaking Skill of the $9^{\text {th }}$ Grade Students of MTs Al-Ihsan Jakarta Barat improves students speaking performance or not. The post-test after was given after the treatment of both experimental and control classes. The writer used oral test to collect the data. The post-test was administrated to the students in order to see the students' speaking performance after being taught with Multiple Intelligences (MI) on Developing Speaking Skill of the $9^{\text {th }}$ Grade Students of MTs Al-Ihsan Jakarta Barat and to compare the result with the students' speaking performance in control class. The data of the study were analyzed statistically. The writer assessed the speaking of the students based on the 
following rubric from Brown (2014, p. 172):

Table 1. Speaking Component Assessment

\begin{tabular}{|c|c|c|c|}
\hline No. & ASPECT & SCORE & INDICATORS \\
\hline \multirow[t]{5}{*}{1.} & \multirow[t]{5}{*}{ Pronunciation } & 5 & Easy to understand and has native speaker's accent. \\
\hline & & 4 & Easy to understand with certain accent. \\
\hline & & 3 & $\begin{array}{l}\text { There are some problems in pronunciation made listener should more } \\
\text { concentration and sometimes there is misunderstanding. }\end{array}$ \\
\hline & & 2 & $\begin{array}{l}\text { Difficult to understand because there is problem in pronunciation, } \\
\text { asked to repeat. }\end{array}$ \\
\hline & & 1 & The serious pronunciation so it can not be understood. \\
\hline \multirow[t]{5}{*}{2.} & \multirow[t]{5}{*}{ Grammar } & 5 & There is no or little mistake in grammar. \\
\hline & & 4 & $\begin{array}{l}\text { Sometimes makes mistake in grammar, but it does not influence the } \\
\text { meaning. }\end{array}$ \\
\hline & & 3 & Often makes mistake in grammar and it influences the meaning. \\
\hline & & 2 & $\begin{array}{l}\text { There are many mistakes in grammar which made hinder in meaning } \\
\text { and should re-arrange sentence. }\end{array}$ \\
\hline & & 1 & The grammar mistake is so bad so it is difficult to understand. \\
\hline \multirow[t]{5}{*}{3.} & \multirow[t]{5}{*}{ Vocabulary } & 5 & Using vocabulary and expression like native speaker. \\
\hline & & 4 & Sometimes using vocabulary which is not appropriate. \\
\hline & & 3 & Sometimes using vocabulary which is not appropriate. \\
\hline & & 2 & Using wrong vocabulary and it is limited so it is difficult to understand. \\
\hline & & 1 & vocabulary is so limited so conversation impossible to occur. \\
\hline \multirow[t]{5}{*}{4.} & \multirow[t]{5}{*}{ Fluency } & 5 & Speech is smooth as a native speaker's. \\
\hline & & 4 & The fluency is disturbed by language problem. \\
\hline & & 3 & The fluency is disturbed more by language problem. \\
\hline & & 2 & $\begin{array}{l}\text { Speech is frequently hesitant and jerky; sentences may be left } \\
\text { uncompleted. }\end{array}$ \\
\hline & & 1 & $\begin{array}{l}\text { Speech is so halting and fragmentary that conversation is virtually } \\
\text { impossible. }\end{array}$ \\
\hline \multirow[t]{5}{*}{5.} & \multirow[t]{5}{*}{ Comprehension } & 5 & Understand all without any difficulties \\
\hline & & 4 & Understand almost all, although there is repetition in certain part. \\
\hline & & 3 & Understand most of what she/he talks in slow speaking. \\
\hline & & 2 & Difficult to understand what she/he talks. \\
\hline & & 1 & Can not understand although in simple conversation. \\
\hline
\end{tabular}

In the end, both of control and experimental students post-test results were compared by applying t-test to determine how much influence of Multiple Intelligences (MI) on Developing Speaking Skill of the $9^{\text {th }}$ Grade Students of MTs Al-Ihsan Jakarta Barat Method in improving students' speaking skill. The fomula of the t-test with formula as follows (Gay, Mills and Airasian, 2012, p. 338)

$$
t=\frac{\chi_{1}-\chi_{2}}{\sqrt{\left(\frac{S S_{1}+S S_{2}}{n_{1}+n_{2}-2}\right)\left(\frac{1}{n_{1}}+\frac{1}{n_{2}}\right)}}
$$

$\mathrm{t} \quad=\mathrm{t}$ test
$=$ the mean or arithmetic average, of the scores by gained of $\mathrm{X}_{1}$ variable and $\mathrm{X}_{2}$ variables scores, which are calculated with the formula:

$$
x=\frac{\sum X}{N}
$$

$\sum \mathrm{X} \quad=$ The sum of $\mathrm{X}_{1}$ variable and $\mathrm{X}_{2}$ variable scores and the formula for the standard $\mathrm{q}$ deviation is:

$\mathrm{SD}=\sqrt{\frac{S S}{N-1}}$, where $=\sum x^{2}-\left(\frac{\sum x}{N}\right)$

$\mathrm{N}=$ Number of cases

$\mathrm{df}=$ degree of freedom with formula $\mathrm{N}$ 1 


\section{FINDING AND DISCUSSION}

he Analysis of the Data was in significance level of $5 \%$ with Degree of Freedom (df). The value of df is 70 at degree of significance $5 \%$ or t-table is 1.98 . The result is $2.228>1.98$. The results of the data analysis showed that by using the t-test formula, $t_{0}$ (tobservation) is higher than $t_{t}(t$-table). It means that was accepted. There is a significant difference between using Multiple Intelligences approach on developing speaking skills in teaching speaking expressions and without using the approach.

Based on the result of t-test calculation above, 2.228 was obtained in the degree of freedom (df) of 70, with the degree of significance $5 \%$. The result of calculation revealed $t_{0}$ (t-observation) $2.228>t_{t}$ (t-table) 1.98. Since $t_{o}$ was higher than $t_{t}$ score obtained from the result of the calculation, the alternative hypothesis (Ha) was accepted while the null hypothesis (Ho) was rejected.

From the explanation above, it can be seen that there is a significant difference between using Multiple Intelligences approach on developing speaking skills in teaching speaking expressions and without using the approach. It can be concluded that using Multiple Intelligences approach on developing speaking skills gives significant effect on students' speaking skill in ninth grade students of MTs AlIhsan West Jakarta.

In summary, from the results above, the experimental class score is higher than the control class. It can be said that Multiple Intelligences (MI) on Developing Speaking Skill of the $9^{\text {th }}$
Grade Students of MTs Al-Ihsan Jakarta Barat.

\section{CONCLUSION}

he result of the research shows
that the students' speaking
achievement improves. There is significant difference between the students' speaking scores before and after being taught by using approach Multiple Intelligences. The average of the students' speaking score using Multiple Intelligences was 74.97 and without using Multiple Intelligences showed 70.36. It means that the score of the students after they are taught by using approach Multiple Intelligences is higher than the score before they are taught.

Then, from the findings of the study and interpretation of the data, the value of $t_{\text {count }}(2.23)$ was higher than the value of $t_{\text {table }}(1.98)$ at the significance level $5 \%$. It can be concluded that the null hypothesis $\left(\mathrm{H}_{0}\right)$ was rejected and alternative hypothesis $\left(\mathrm{H}_{1}\right)$ was accepted. Thus, this study concludes that using approach Multiple Intelligences gives significant effect on students' speaking skills in the ninth grade students of MTs Al-IhsanWest Jakarta.

\section{REFERENCES}

Abdallah, M. M. S. (2005). The Effect of Using a Multiple Intelligences-Based Training Programme on Developing English Majors' Oral Communication Skills. (Assiut University).

Bailey, K. M. (2005). Practical English Language Teaching: Speaking. McGraw-Hill ESL/ELT (p. 199). McGraw-Hill ESL/ELT.

Greenbaum, S., \& Nelson, G. (1996). The International Corpus of English (ICE)

Project. World 
Englishes, 15(1),

$3-15$.

https://doi.org/10.1111/j.1467-

971X.1996.tb00088.x

Harmer, J. (2001). The Practice of English Language Teaching. London: Pearson Education Limited.

Jondeya, R. S. The Effectiveness Of Using Information Gap On Developing Speaking Skills For The Eighth Graders In Gaza Governorate Schools. Diss. Al-Azhar University-Gaza, 2011.

Kline, J.A. 2001. Speaking Effectively: A Guide for Air Force Speakers. Alabama:Air University Press

Kramsch, C. J. (1993). Context and culture in language teaching. Oxford: Oxford University Press.

Nunan, D. (2002). Listening in Language Learning. In J. C. Richards \& W. A. Renandya (Eds.), Methodology in Language Teaching: An Anthology of Current Practice (pp. 238-241). Cambridge: Cambridge University Press.

Richards, J. C. (2008). Teaching Listening and Speaking: From Theory to Practice. New York: Cambridge University Press.

Turk, C. (2003). Effective Speaking: Communicating in Speech. London: E. \& F.N. Spon.

Purpura, J. E. (2013). Assessing Grammar. In The Companion to Language Assessment (pp. 100124). John Wiley \& Sons, Inc. https://doi.org/10.1002/97811184 11360.wbcla147 